\title{
ANALISIS PENGELOLAAN PIUTANG DAN POTENSI PIUTANG YANG TIDAK TERTAGIH SEBAGAI TINDAK LANJUT KEBIJAKAN PEMBAYARAN KREDIT PADA BIMBINGAN BELAJAR X DI MADIUN
}

\author{
Rizka Hardiyanti ${ }^{1)}$ \\ rizkahardiyanti@gmail.com \\ Universitas PGRI Madiun
}

\begin{abstract}
This study aims to analyze the management accounts and the potential doubtful as a follow-up loan payments policy on tutoring $\mathrm{X}$ in Madiun. Accounts receivable is one type of accounting transactions dealing with the billing of consumers is owed on a person, a company, or an organization for goods and services that has been given to the consumer. Results of research conducted at the Institute of tutoring $\mathrm{X}$ in Madiun, the researchers conclude that the management of receivables and the potential doubtful at a tutoring agency $\mathrm{X}$ in Madiun there have been improvements in the new school year 2016-2017. So in the new academic year 2015-2016 is no longer doubtful, but still no payment policy on credit to be paid each maturity. Keywords: Receivables Management, Potential Accounts Receivables photo and Follow-Up Credit Policy.
\end{abstract}

\section{ABSTRAK}

Penelitian ini bertujuan untuk menganalisis pengelolaan piutang dan potensi piutang yang tidak tertagih sebagai tindak lanjut kebijakan pembayaran kredit pada bimbingan belajar X di Madiun. Piutang merupakan salah satu jenis transaksi akuntansi yang mengurusi penagihan konsumen yang berhutang pada seseorang, suatu perusahaan, atau suatu organisasi untuk barang dan layanan yang telah diberikan pada konsumen tersebut. Hasil penelitian yang dilakukan pada Lembaga bimbingan belajar $\mathrm{X}$ di Madiun, maka peneliti mengambil kesimpulan bahwa pengelolaan piutang dan potensi piutang yang tidak tertagih di lembaga bimbingan belajar X di Madiun sudah ada perbaikan di tahun ajaran baru 2016-2017. Sehingga di tahun ajaran baru 2015-2016 sudah tidak ada lagi piutang yang tidak tertagih, tetapi masih ada kebijakan pembayaran secara kredit yang harus dibayarkan setiap jatuh tempo. Kata Kunci: Pengelolaan Piutang, Potensi Piutang yang Tidak Tertagih dan Tindak Lanjut Kebijakan Kredit.

\section{PENDAHULUAN}

Pada umumnya perusahaan bertujuan menghasilkan laba dalam mempertahankan usahanya. Salah satu kegiatan operasional tersebut adalah lebih menyukai penjualan tunai dibandingkan dengan kredit, namun adanya persaingan maka perusahaan melakukan penjualan kredit yang akan menimbulkan piutang. seperti permasalahan yang terjadi di sebuah lembaga bimbingan belajar, ketika customer mendaftar mereka diberikan pilihan yaitu membayar secara lunas atau kredit, ketika sudah memilih pembayaran secara kredit dan sepakat untuk membayar sebelum jatuh tempo, terkadang masih saja customer meminta keringanan waktu lagi, sedangkan persyaratan untuk mendapatkan fasilitas seperti buku harus segera membayar minimal angsuran pertama.

Berbagai cara yang ditempuh oleh pihak manajemen untuk meningkatkan volume penjualan mulai dari promosi, pemberian hadiah dan potongan harga, sampai dengan penjualan secara kredit. Perusahaan menyadari bahwa persaingan 
yang sangat ketat mengharuskan perusahaan untuk terus bertahan untuk menghasilkan laba. Oleh karena itu perusahaan memberikan suatu kebijakan piutang yang mengandung empat unsur yaitu :

1. Unsur pemberian kredit

2. Prosedur pemberian kredit

3. Syarat dan seleksi pemberian kredit

4. Prosedur penagihan piutang

Piutang biasanya timbul karena kebijakan kredit dari perusahaan barang atau jasa kepada pihak lain. Namun, terkadang terjadi suatu keadaan tidak tertagihnya sebagai piutang oleh perusahaan, hal ini merupakan konsekuensi dari kebijakan kredit yang biasanya dilakukan oleh perusahaan yang bertujuan meningkatkan penjualan secara kredit.

Lembaga bimbingan belajar yang berpusat di Bandung ini memiliki cabang yang tersebar diseluruh Indonesia salah satunya berada di J1 Sulawesi No 17 Madiun. Aktivitas usaha perusahaan ini yaitu melakukan kegiatan belajar mengajar kepada siswa dari berbagai macam sekolah di Madiun dan sekitarnya. Dalam hal ini, sebelum siswa mengikuti kegiatan belajar mereka melakukan pendaftaran terlebih dahulu. Dari lembaga menawarkan program mulai dari kelas regular sampai kelas executive ( gold) selain pembayaran secara lunas yang tentunya disertai dengan diskon bisa juga dibayarkan dengan kredit, sehingga perusahaan memiliki piutang usaha yang jumlahnya besar. Oleh karena itu, pengelolaan piutang yang tidak tertagih harus segera di tindak lanjuti dengan melakukan penagihan melalui telephon dan surat pemberitahuan. Kebijakan piutang yang efektif dan prosedur penagihan yang tepat waktu sangat penting untuk ditetapkan, agar dapat mengurangi potensi adanya piutang tak teragih. Kebijakan piutang yang baik adalah kebijakan piutang yang bisa mengoptimalkan keuntungan dan kerugian dari piutang.
Penelitian pendahulu yang dilakukan oleh penulis, terdapat sejumlah piutang usaha yang sudah melewati tanggal jatuh tempo tetapi belum dilunasi oleh konsumen. Hal ini akan menyebabkan kerugian pada perusahaan dan juga mempengaruhi kelangsungan hidup perusahaan. Berdasarkan uraian di atas, penulis tertarik untuk meneliti lebih jauh guna mengetahui bagaimana sebenarnya pengelolaan piutang usaha pada lembaga bimbingan belajar.

\section{KAJIAN TEORI}

Piutang sendiri timbul dari penjualan barang atau jasa karena terdapat kebijakan secara kredit menurut Baridwan (2004:129), yaitu :

1. Pembeli membutuhkan barang dan jasa secara langsung, namun tidak bisa mereka bayar secara langsung atau lebih menyukai untuk membayar secara kredit atau cicil.

2. Penjual dapat menjual lebih banyak dengan melakukan penjualan kredit dibandingkan dengan hanya melakukan penjualan tunai, menurut Warren, Reeve, Fess (2005:3), yang diterjemahkan oleh Aria Farahmita, "piutang usaha timbul akibat adanya penjualan kredit".

Menurut Kieso (2008:350) yang diterjemahkan oleh Emill Salim piutang tak tertagih adalah kerugian pendapatan, yang memerlukan, melalui ayat jurnal pencatatan yang tepat pada akun, penurunan aktiva piutang usaha serta penurunan yang berkaitan dengan laba. Piutang yang telah ditetapkan sebagai piutang tak tertagih bukan merupakan aktiva lagi, oleh karena itu harus dikeluarkan dari pos piutang dalam neraca. Piutang tak tertagih merupakan suatu kerugian, dan kerugian ini harus dicatat sebagai beban, yaitu beban piutang tak tertagih yang disajikan dalam laporan laba rugi. 
Menurut ikatan Akuntan Indonesia, (pernyataan Standar Akuntansi Keuangan (PSAK) 2002:No. 9, part 7), piutang harus dinyatakan sebesar jumlah kotor tagihan, dikurangi dengan taksiran jumlah yang tidak dapat ditagih.

Perusahaan akan memperlakukan biaya kerugian piutang sebagai pendapatan lain-lain, ketika diterima sejumlah uang dari pelanggan yang hutangnya telah dihapuskan pada periode sesudah terjadinya penghapusan piutang. Jika terjadinya pada periode dimana piutang dihapuskan, maka dilakukan dengan mengurangi biaya kerugian piutang (Reeve, Warren, dan Fees 2005:321).

Atmaja (2006, h.268) menyatakan bahwa pemberian kredit mengandung empat unsur yaitu periode kredit, standar kredit, kebijakan penagihan, kebijakan diskon.

Brigham dan Houston, (2006 : 174) kebijakan kredit terdiri dari empat variable yaitu :

a. Periode kredit, merupakan jangka waktu yang diberikan kepada pembeli untuk melunasi pembelinya.

b. Standart kredit, yang memiliki arti kekuatan keuangan yang diisyaratkan atas pelanggan yang menerima fasilitas kredit.

c. Kebijakan penagihan, yang diukur oleh seberapa keras atau lunaknya perusahaan dalam usaha menagih akun-akun yang lambat pembayarannya.

d. Kebijakan diskon, yang diberikan untuk pembayaran lebih cepat, termasuk persentase potongan harga dan seberapa cepat pembayaran harus dilakukan untuk memenuhi persyaratan pembelian potongan harga.

Menurut Kasmir (2008, h.75) ada beberapa cara yang dilakukan untuk melakukan penagihan piutang yaitu: a. Melalui Surat

Bilamana pembayaran hutang dari pelanggan sudah lewat beberapa hari tetapi belum dilakukan pembayaran maka perusahaan dapat mengirim surat untuk mengingatkan atau menegur pelanggan yang belum membayar hutangnya yang jatuh tempo. Apabila hutang tersebut belum juga dibayar setelah beberapa hari surat dikirimkan maka dapat dikirimkan lagi surat dengan teguran yang lebih keras.

b. Melalui Telepon

Apabila setelah pengiriman surat teguran ternyata tagihan tersebut belum juga dibayar maka bagian kredit dapat menelepon pelanggan dan secara pribadi memintanya untuk segera melakukan pembayaran. Kalau dari hasil pembicaraan tersebut ternyata pelanggan mempunyai alasan yang dapat diterima maka mungkin perusahaan dapat memberikan perpanjangan sampai jangka waktu tertentu.

c. Kunjungan Personal

Melakukan kunjungan secara personal atau pribadi ke tempat customer sering kali digunakan karena dirasakan sangat penting dalam usaha-usaha pengumpulan piutang.

\section{METODE PENELITIAN}

Penelitian ini menggunakan metode penelitian eksperimen. Gay (1981: 207-208) menyatakan bahwa metode penelitian eksperimental merupakan satu-satunya metode penelitian yang dapat menguji secara benar hipotesis menyangkut hubungan kausal (sebab akibat). Sumber data dalam penelitian adalah subjek dari mana data dapat diperoleh. Penggunaan data yang diperlukan mencakup data primer. Data primer adalah data yang diperoleh atau dikumpulkan langsung di lapangan oleh 
orang yang melakukan penelitian atau yang bersangkutan yang memerlukannya. Data tersebut melalui wawancara dan hasil observasi dari dokumen yang terkait pada analisis pengelolaan piutang dan potensi piutang yang tidak tertagih sebagai tindak lanjut kebijakan pembayaran kredit pada bimbingan belajar X di kota Madiun, seperti pemeriksaan terhadap otorisasi bukti transaksi dan kelengkapan dokumen lainnya.

\section{Teknik Analisis Data}

Peneliti melakukan analisis data untuk mengukur efektifitas pengelolaan piutang dan potensi yang tidak tertagih sebagai tindak lanjut penjualan kredit pada lembaga bimbingan belajar $\mathrm{X}$ di Madiun yang meliputi:
a. Analisis Struktur Organisasi
b. Analisis Sistem Otorisasi dan Prosedur Pencatatan Akuntansi
c. Analisis Praktik yang Sehat
d. Analisis Mutu Karyawan
e. Analisis Efektifitas Pengelolaan Piutang

Analisis ini dilakukan untuk mengetahui hasil dan tujuan dari hasil menganalisis kegiatan dan proses pengelolaan piutang apakah sudah sesuai dengan standar operational prosedur (SOP).

\section{HASIL DAN PEMBAHASAN}

Sejarah Singkat Bimbingan Belajar X di Kota Madiun

Latar belakang pendirian lembaga ini adalah adanya mata rantai yang terputus dari link informasi Sekolah Lanjutan Tingkat Atas (SLTA) dengan dunia Perguruan Tinggi Negeri (PTN). Posisi inilah yang diisi oleh Bimbingan Belajar $X$ untuk berfungsi sebagai jembatan dunia SLTA terhadap dunia PTN mengenai informasi jurusan PTN (prospek dan tingkat persaingannya), pemberian materi pelajaran yang sesuai dengan ruang lingkup bahan uji seleksi penerimaan mahasiswa baru dan pemberian metode-metode inovatif dan kreatif menyelesaikan soal-soal tes masuk PTN sehingga membantu para siswa lulusan SLTA memenuhi keinginan mereka memasuki PTN. Meskipun pada awalnya hingga tahun 1992 Bimbingan belajar X hanya ada di Bandung, pada tahun 1993 dibuka cabang pertama di Denpasar. Dan pengembangan secara serius dilakukan mulai tahun 1995. Sejak itu pertumbuhan cabang-cabang Bimbingan belajar X benarbenar tidak terbendung. Image Bimbingan belajar X yang sangat kuat telah merambah ke seluruh Nusantara sehingga setiap cabang baru dibuka langsung diserbu oleh para siswa.

\section{Visi dan Misi}

Visi

Ikut mencerdaskan kehidupan bangsa dan memberikan kontribusi dalam peningkatan mutu pendidikan nasional, serta meningkatkan budaya belajar masyarakat.

Misi

a) Menjadi wadah pengkajian dan pengembangan ilmu pengetahuan dasar dengan komitmen total kepada inovasi dan kreativitas.

b) Memberikan metode yang unik dan unggul untuk menguasai basic science.

c) Mewujudkan kepuasan siswa melalui keunggulan :

1. Produk jasa yang konseptual.

2. Harga yang pantas dan terjangkau.

3. Lokasi yang strategis.

4. Proses pelayanan yang cepat.

5. Sumber daya manusia yang ramah,terampil,dan memiliki kompetisi.

6. Ruangan dan lingkungan yang nyaman dan asri dengan fasilitas yang lengkap.

7. Informasi yang lengkap dan terpercaya. 


\section{Tujuan Lembaga Bimbingan Belajar X di Madiun}

Membantu para siswa mengatasi kesulitan belajar melalui bimbingan staf pengajar yang berkualitas dan berwawasan luas dengan buku panduan belajar yang lengkap dan sistematis. Memberikan informasi pendidikan yang sangat lengkap baik untuk tingkat SD,SMP,SMA maupun perguruan tinggi. Memberikan strategi bersaing bagi para siswa untuk memasuki jenjang pensisikan yang lebih tinggi sehingga sukses memasuki SMP, SMA dan perguruan tinggi favorit dan terkemuka sesuai dengan minat dan kemampuan.

\section{Ruang Lingkup Divisi Lembaga bimbingan belajar X di Madiun}

Ruang lingkup Lembaga bimbingan belajar $\mathrm{X}$ di Madiun dari masing-masing divisi dapat diuraikan sebagai berikut :
1. Divisi Keuangan dan Akuntansi

2. Divisi Sistem Informasi (IT)

3. Divisi Akademik Pengajar

4. Divisi Akademik Kesiswaan

5. Divisi Operasi

6. Divisi Logistik

7. Divisi Marketing

\section{A. Struktur Organisasi}

Sebagai upaya meningkatkan pelayanan bagi customer secara umum, meningkatkan kualitas sumber daya manusia, meningkatkan produktivitas, dan efektivitas kerja di Lembaga bimbingan belajar X di Madiun.Adapun struktur organisasi di Lembaga bimbingan belajar X di Madiun dapat dilihat pada gambar dibawah ini.

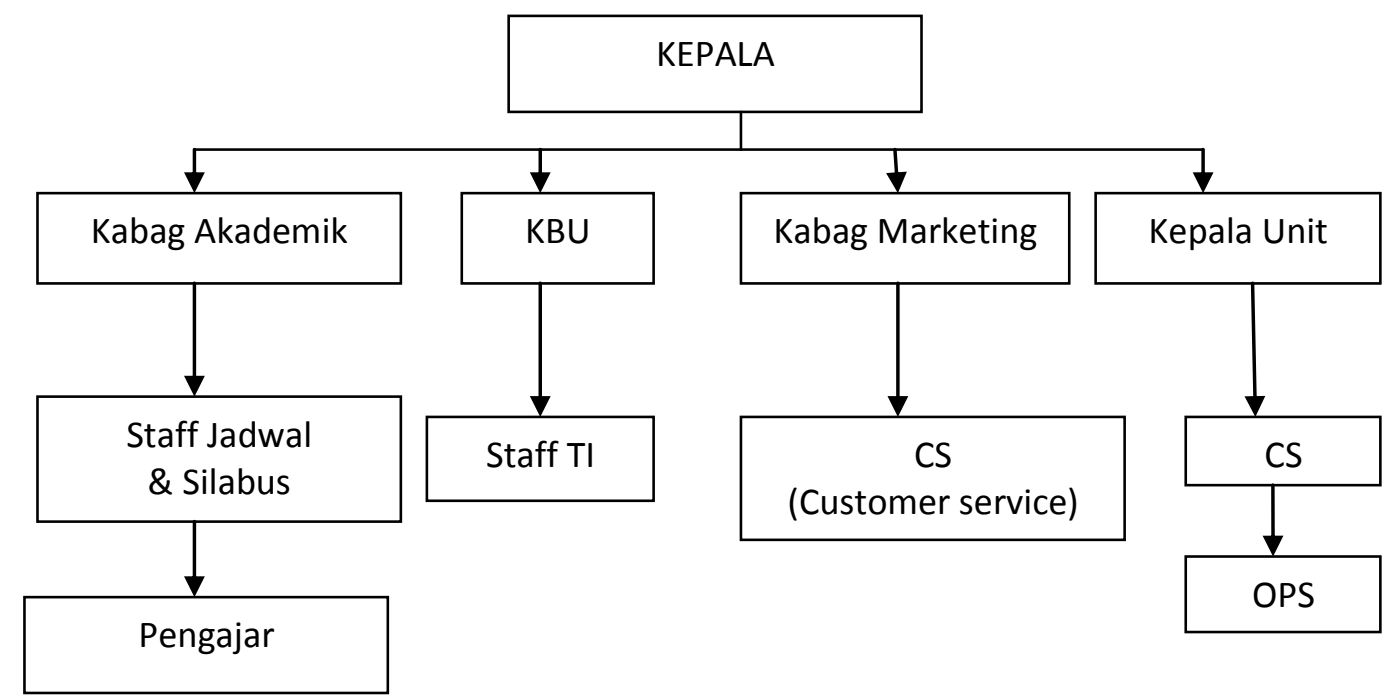

Gambar 1

Struktur organisasi Lembaga Bimbingan Belajar X di Madiun

Kebijakan Pembayaran Kredit Pada Bimbingan Belajar X di Madiun.

Lembaga bimbingan $X$ di Madiun memberikan kebijakan dalam pembayaran secara kredit sebagai berikut :

a. Periode kredit, yaitu jangka panjang yang diberikan kepada customer untuk melunasi pembayaran dalam waktu empat bulan dengan besar angsuran ditentukan dari lembaga bimbingan belajar.

b. Standart kredit, fasilitas akas diberikan kepada customer jika sudah 
melakukan pembayaran minimal angsuran pertama.

c. Kebijakan penagihan, yaitu melakukan penagihan yang lambat dalam pembayaranya sesuai dengan jatuh tempo yang ditentukan.

d. Kebijakan diskon, yaitu diberikan kepada siswa yang pernah mendaftar di di lembaga bimbingan belajar ini pada tahun lalu maka gratis biaya pendaftaran dan tetap mendapatkan potongan diskon siswa lanjutan walaupun membayar secara kredit.

Dari analisis kebijakan pembayaran kredit sudah dilakukan secara baik oleh bagian penagih ke customer yang melakukan pembayaran secara kredit. Namun, permasalahan yang timbul sehingga piutang tidak tertaih adalah bagian penagih yang kurang di dukung dengan bagian kesiswaan yang sebaiknya ikut melakukan pendekatan terhadap siswa, sehingga siswa bisa menyampaikan ke orang tuanya untuk melakukan pembayaran.

\section{Sistem Pengelolaan Piutang pada Lembaga Bimbingan Belajar $X$ di Madiun}

\section{Lingkungan pengendalian}

Lingkungan pengendalian ini tercermin sikap dan tindakan semua karyawan mengenai pengendalian.Lingkungan pengendalian erat hubunganya dengan pelaksanaan oprasional, yaitu para karyawan yang melakukan kegiatan sehingga secara langsung akan menetukan corak organisasi dan mempengaruhi kesadaran mengendalikan para karyawannya yang terdiri dari :

a. Komitmen kepada integritas dan nilai etika.

Lembaga bimbingan belajar X di Madiun memiliki peraturan-peraturan yang diterapkan oleh manajemen berupa tata cara kepegawaian dan perilaku, aturan tersebut kemudian dikomunikasikan kepada setiap para karyawan dan harus dilaksanakan. Dalam pengelolaan pengelolaan piutang, integritas dan etika karyawan cukup baik. Hal ini terlihat dari kejujuran dalam pencatatan transaksi yang dilakukan.

b. Komitmen Terhadap Kompetensi

Komitemen terhadap kompetensi Lembaga bimbingan belajar $\mathrm{X}$ di Madiun cukup baik. Hal ini dilihat dari setiap karyawan yang bekerja sesuai dengan bidang dan pengetahuan yang dimiliki serta memenuhi syarat untuk menduduki posisi tertentu.

c. Struktur Organisasi

Struktur organisasi yang dilaksanakan Lembaga bimbingan belajar $\mathrm{X}$ di Madiun dinilai cukup baik. Hal ini dilihat dari setiap perangkat perusahaan memiliki tugas dan fungsi masing-masing. Seperti halnya fungsi akuntansi sudah terpisah dengan fungsi penagihan dan fungsi penerimaan kas serta fungsi penerimaan kas sudah terpisah dari fungsi akuntansi.

d. Pemberian Wewenang dan Tanggung Jawab.

Pemberian wewenang dan tanggung jawab pada Lembaga bimbingan belajar $\mathrm{X}$ di Madiun dinilai sudah 
baik. Semua karyawan sudah melaksanakan pekerjaan sesuai dengan wewenang dan tanggung jawabnya yang sudah di delegasikan oleh pimpinan.

e. Kebijakan Tentang Sumber Daya Manusia.

Lembaga bimbingan belajar X di Madiun jelas telah memenuhi syarat yang baik dimana pimpinan selalu memberikan perhatian agar hidup karyawan terjamin dengan cara memberikan gaji yang memadai dan tunjangan-tunjangan lainya. Namun, timbul masalah piutang yang tidak tertagih karena kurangnya perhatian dari bagian kesiswaan yang kurang membantu menyampaikan ke siswa, sehingga piutang yang tidak tertagih semakin naik.

\section{Penilain Risiko}

Penilaian risiko bertujuan untuk mengidentifikasi, menganalisis dan mengelola risiko yang berhubungan dengan pengendalian intern di dalam perusahaan. Risiko yang disebabkan oleh faktor intern dan ekstern, risiko dapat timbul oleh keadaan sebagai berikut :

a. Perubahan Lingkungan Perusahaan

Perubahan peraturan atau lingkungan oprasional dapat mengakibatkan perubahan dalam tekanan persaingan dan resiko yang berbeda. Lembaga bimbingan belajar $\mathrm{X}$ di Madiun terus melakukan penyempurnaan pengendalian intern terhadap kas dan adanya pengawasan dari pengawas independen untuk mengontrol pengelolaan kas agar terhindar dari pencurian dan manipulasi.

b. Karyawan Baru

Dengan adanya karyawan baru yang masih mempunyai semangat kerja tinggi akan memacu karyawan lain untuk bekerja dengan lebih semangat dan baik. Untuk mendapatkan karyawan baru yang baik dan berpotensi, Lembaga bimbingan belajar X di Madiun menyeleksi dengan ketat dan sesuai dengan prosedur yang ada.

c. Teknologi Baru

Teknologi yang digunakan di Lembaga bimbingan belajar X di Madiun sudah menggunkan teknologi komputerisasi sehingga dapat mempermudah karyawan dalam bekerja dan kemungkinan besar sulit dalam melakukan kecurangan selain itu dengan teknologi komputerisasi dapat menghemat waktu kerja lebih cepat dan akurat.

\section{Aktivitas Pengendalian}

Aktivitas pengendalian Lembaga bimbingan belajar $\mathrm{X}$ di Madiun dalam pengelolaan piutang kasir selalu membuat laporan harian beserta uang yang harus disetorkan ke bank pada hari itu juga. Sebelum memberikan otorisasi laporan tersebut lebih dahulu dicocokan antar jumlah uang yang diterima dengan transaksi tersebut. Sedangkan dalam pengeluaran untuk keperluan operasional, bagian pebendaharan mengeluarkan uang setelah mendapat persetujuan dan diotorisasi dari bagian keuangan. Kemudian melaporkan kebagian akuntansi. Dalam hal ini, Lembaga bimbingan belajar $\mathrm{X}$ di Madiun telah menjalankan aktivitas pengendalian dengan baik dalam melakukan otorisasi.

\section{Informasi dan Komunikasi}

Upaya untuk mencapai pengendalian intern terhadap pegelolaaan piutang yang efektif, maka informasi dan komunikasi harus terjalin dengan baik. masalah yang ada di dalam bimbingan belajar $X$ di Madiun informasi dan komunikasi belum berjalan baik, karena kurangnya informasi dan komunikasi ke siswa mengakibatkan siswa yang belum membayar maish diberikan kesempatan untuk bimbingan belajar. Kemudian ada siswa yang sudah dikasih 
uang oleh oran tuanya tapi belum dibayarkan. Dan tidak ada pembinaan dari kesiswaan terhadap siswa yang bermasalah. Sehingga, menyebabkan potensi piutang tidak tertagih semakin besar.

\section{Pemantauan}

Upaya untuk memaksimalkan aktivitas oprasional, evaluasi pemantauan tentu sangat dibutuhkan agar semua kegiatan perusahaan berjalan sebagaimana semestinya. Pengawas Lembaga bimbingan belajar X di Madiun sudah melaksankan tugasnya dengan baik dimana pengawasanya dilakukan pada suatu waktu tertentu. Akan tetapi akan lebih baik apabila pengawas melakukan pengawasan sesering mungkin. Dalam hal ini dilakukan untuk mengukur kinerja ataupun aktivitas oprasional perusahaan.

\section{B. Evaluasi dan Perbandingan data Penagihan dalam pengelolaan piutang dan potensi piutang yang tidak tertagih}

Dalam pengelolaan piutang sangat penting untuk mendapatkan efektifitas dan efisiensi dari kegiatan yang ada di Lembaga bimbingan belajar X di Madiun. Maka, diperlukan manajemen pengelolaan piutang yang efektif dan efisien agar jumlah dana yang diinvestasikan dalam piutang sesuai dengan tingkat kemampuan perusahaan sehingga tidak mengganggu aliran kas. Berikut adalah data perbandingan penagihan tahun ajaran 2014-2015 dan 2015-2016 di Lembaga bimbingan belajar X di Madiun :

Tabel 1. Data Penunggak Tahun ajaran 2014-2015

\begin{tabular}{ccllll}
\hline Program & $\begin{array}{l}\text { Total Biaya } \\
\text { yang Harus } \\
\text { Dibayar }\end{array}$ & $\begin{array}{l}\text { Jumlah yang } \\
\text { Sudah Dibayar }\end{array}$ & $\begin{array}{c}\text { Sisa yang } \\
\text { Harus Dibayar }\end{array}$ & $\begin{array}{l}\text { Hasil } \\
\text { Penagihan }\end{array}$ \\
\hline 1 & Gold & Rp. 6.500.000,00 & Rp. 5.500.000,00 & Rp. 1.000.000,00 & $\begin{array}{l}\text { Telepon } \\
\text { tidak } \\
\text { diangkat }\end{array}$ \\
2 & Silver & Rp. 2.660.000,00 & 0 & Keluar \\
3 & Reguler & & $\begin{array}{l}\text { Rp. 100.000,00 } \\
\text { (Pendaftran) }\end{array}$ & Rp. 2.660.000,00 & Batal Les \\
4 & Reguler & & $\begin{array}{l}\text { Rp. 100.000,00 } \\
\text { (Pendaftran) }\end{array}$ & Batal Les \\
5 & Aksel & Rp. 4.800.000,00 & $\begin{array}{l}\text { Rp. 3.500.000,00 } \\
\text { Rp. 1.300.000,00 }\end{array}$ & $\begin{array}{l}\text { Selalu } \\
\text { menjanjikan }\end{array}$ \\
6 & Silver & Rp. 5.000.000,00 & $\begin{array}{l}\text { Rp. 4.000.000,00 } \\
\text { Rp. 1.000.000,00 }\end{array}$ & Minta waktu \\
7 & Silver & Rp. 3.500.000,00 & $\begin{array}{l}\text { Rp. 100.000,00 } \\
\text { (Pendaftaran) }\end{array}$ & Rp. 3.500.000,00 & Keluar \\
\hline
\end{tabular}

Sumber : (Data Keuangan)

Dari tabel diatas dijelaskan bahwa pada tahun ajaran 2014-2015 ada penunggak di lembaga bimbingan belajar X di Madiun yang tidak terbayar sampai siswa sudah lulus dari lembaga bimbingan belajar $\mathrm{X}$ di Madiun. Jumlah penunggak di tahun ajaran 2014-2015 sebanyak tujuh siswa yang belum membayar bimbingan belajar. Bagi siswa yang belum melakukan pelunasan, mereka belum mendapatkan fasilitas lengkap dari lembaga bimbingan belajar X di Madiun. 
Tabel 2. Data Penunggak Tahun ajaran 2015-2016

\begin{tabular}{|c|c|c|c|c|c|}
\hline No & Program & $\begin{array}{c}\text { Total Biaya } \\
\text { yang Harus } \\
\text { Dibayar }\end{array}$ & $\begin{array}{l}\text { Jumlah yang } \\
\text { Harus Dibayar }\end{array}$ & $\begin{array}{c}\text { Sisa yang Harus } \\
\text { Dibayar }\end{array}$ & $\begin{array}{l}\text { Hasil } \\
\text { Penagihan }\end{array}$ \\
\hline 1 & Reguler & Rp. 5.700.000,00 & Rp. $2.200 .000,00$ & Rp. 3.500.000,00 & $\begin{array}{l}\text { Diusahakan } \\
\text { akhir } \\
\text { maret }\end{array}$ \\
\hline 2 & Reguler & Rp 5.050.000,00 & Rp 100.000,00 & Rp 4.950.000,00 & $\begin{array}{l}\text { Siswa tidak } \\
\text { lanjut les }\end{array}$ \\
\hline 3 & Gold & $\operatorname{Rp} 8.692 .500,00$ & $\operatorname{Rp} 7.850 .000,00$ & $\operatorname{Rp} 842.500,00$ & $\begin{array}{l}\text { Belum } \\
\text { dilakukan } \\
\text { penagihan }\end{array}$ \\
\hline 4 & Silver & Rp 4.200.000,00 & Rp 1.600.000,00 & Rp 2.600.000,00 & $\begin{array}{l}\text { Diusahakan } \\
\text { akhir } \\
\text { maret }\end{array}$ \\
\hline 5 & Silver & Rp 6.507.500,00 & Rp 5.700.000,00 & $\operatorname{Rp} 807.500,00$ & $\begin{array}{l}\text { Diusahakan } \\
\text { akhir maret }\end{array}$ \\
\hline 6 & Reguler & Rp 5.550.000,00 & Rp 3.900.000,00 & Rp 1.650.000,00 & $\begin{array}{l}\text { Belum } \\
\text { dilakukan } \\
\text { penagihan }\end{array}$ \\
\hline 7 & Reguler & Rp 5.600.000,00 & Rp 4.950.000,00 & $\mathrm{Rp} 650.000,00$ & $\begin{array}{l}\text { Belum } \\
\text { dilakukan } \\
\text { penagihan }\end{array}$ \\
\hline 8 & Reguler & Rp 5.600.000,00 & Rp 2.300.000,00 & Rp 3.300.000,00 & $\begin{array}{l}\text { Belum } \\
\text { Konfirmasi } \\
\text { balik }\end{array}$ \\
\hline 9 & Reguler & Rp 5.550.000,00 & $\mathrm{Rp} 4.050 .000,00$ & Rp 1.500.000,00 & $\begin{array}{l}\text { Belum } \\
\text { dilakukan } \\
\text { penagihan }\end{array}$ \\
\hline 10 & Reguler & Rp 4.950.000,00 & Rp 1.000.000,00 & Rp 3.950.000,00 & $\begin{array}{l}\text { Siswa tidak } \\
\text { lanjut les }\end{array}$ \\
\hline 11 & Reguler & Rp 5.700.000,00 & Rp 200.000,00 & Rp 5.500.000,00 & $\begin{array}{l}\text { Siswa tidak } \\
\text { lanjut les }\end{array}$ \\
\hline 12 & Reguler & Rp 5.150.000,00 & Rp 1.500.000,00 & Rp 3.650.000,00 & $\begin{array}{l}\text { Siswa tidak } \\
\text { lanjut les }\end{array}$ \\
\hline 13 & Silver & Rp 7.410.000,00 & Rp 4.500.000,00 & Rp 2.910.000,00 & $\begin{array}{l}\text { Siswa } \\
\text { tidak } \\
\text { lanjut les }\end{array}$ \\
\hline 14 & Reguler & Rp 6.850.000,00 & Rp 2.450.000,00 & Rp 4.400.000,00 & $\begin{array}{l}\text { Siswa } \\
\text { tidak } \\
\text { lanjut les }\end{array}$ \\
\hline 15 & Reguler & Rp 6.800.000,00 & Rp 1.100.000,00 & Rp 5.750.000,00 & $\begin{array}{l}\text { Siswa } \\
\text { tidak } \\
\text { lanjut les }\end{array}$ \\
\hline
\end{tabular}


INVENTORY: Jurnal Akuntansi Vol. 1 No. 1 April 2017

\begin{tabular}{|c|c|c|c|c|c|}
\hline 16 & Reguler & Rp 5.700.000,00 & Rp 1.200.000,00 & $\operatorname{Rp} 4.500 .000,00$ & $\begin{array}{l}\text { Belum } \\
\text { konfirmasi } \\
\text { balik }\end{array}$ \\
\hline 17 & Reguler & Rp 6.850.000 & Rp $1.700 .000,00$ & Rp 5.150.000,00 & $\begin{array}{l}\text { Belum } \\
\text { dilakukan } \\
\text { penagihan }\end{array}$ \\
\hline 18 & Reguler & $\operatorname{Rp} 3.325 .000$ & Rp 1.000.000,00 & Rp 2.325.000,00 & $\begin{array}{l}\text { Siswa tidak } \\
\text { Jadiles }\end{array}$ \\
\hline 19 & Reguler & Rp 6.850 .000 & $\operatorname{Rp} 1.600 .000,00$ & Rp 5.250.000,00 & $\begin{array}{l}\text { Belum } \\
\text { konfirmasi } \\
\text { balik }\end{array}$ \\
\hline 20 & Reguler & Rp 7.695.000 & $\operatorname{Rp} 2.500 .000,00$ & Rp 5.195.000,00 & $\begin{array}{l}\text { Belum } \\
\text { dilakukan } \\
\text { penagihan }\end{array}$ \\
\hline 21 & Gold & Rp 7.300.000 & Rp 4.200.000,00 & Rp 3.100.000,00 & $\begin{array}{l}\text { Belum } \\
\text { dilakukan } \\
\text { penagihan }\end{array}$ \\
\hline 22 & Reguler & Rp 3.150 .000 & Rp 2.000.000,00 & Rp 1.105.000,00 & $\begin{array}{l}\text { Belum } \\
\text { dilakukan } \\
\text { penagihan }\end{array}$ \\
\hline 23 & Silver & Rp 4.560.000 & Rp 3.400.000,00 & Rp 1.160.000,00 & $\begin{array}{l}\text { Belum } \\
\text { dilakukan } \\
\text { penagihan }\end{array}$ \\
\hline
\end{tabular}

Dari tabel 4.3 diatas dijelaskan bahwa pada tahun ajaran 2015-2016 ada penunggak di lembaga bimbingan belajar X di Madiun yang tidak terbayar sampai siswa sudah lulus dari lembaga bimbingan belajar $\mathrm{X}$ di Madiun. Jumlah penunggak di tahun ajaran 2014-2015 sebanyak 23 siswa yang belum membayar bimbingan belajar. Bagi siswa yang belum melakukan pelunasan, mereka belum mendapatkan fasilitas lengkap dari lembaga bimbingan belajar $\mathrm{X}$ di Madiun.

\section{PEMBAHASAN}

\section{Efektivitas Pengelolaan Piutang}

Setelah melakukan penelitian, peneliti berpendapat dalam melakukan pengelolaan piutang di Lembaga bimbingan belajar X di Madiun sudah efektif, baik dalam struktur organisasinya, sistem otorisasi dan pencatatanya. Akan tetapi belum memenuhi unsur-unsur pengendalian intern pengelolaan piutang contohnya kas dalam perjalanan dan kas yang ada ditangan kasir lembaga bimbingan belajar $\mathrm{X}$ di Madiun tidak ada jaminan sehingga apabila

terjadi kerugian yang besar seperti misalnya jika terjadi pencurian bagian yang bersangkutanlah yang akan bertangggungjawab. Selain itu para penagih dan kasir tidak ada jaminan untuk menghindari kerugian akibat penyelewengan kas yang dilakukan oleh karyawan yang diserahi tugas. Untuk itu kas dan kasir serta penagih perlu jaminan untuk menunjang efektivitas pengelolaan kas.

Pelaksanaan pengelolaan piutang dan potensi piutang yang tidak tertagih sebagai tindak lanjut kebijakan pembayaran kredit pada bimbingan belajar X di Madiun dapat menunjang efektivitas penerimaan dan Pengelolaan piutang perusahaan dengan artian semakin baik pengendalian intern yang ada dalam organisasi ataupun perusahaan, maka semakin efektif pengelolaan piutang yang dilakukan. Demikian pula dengan semakin memadai pengendalian intern yang ada dalam perusahaan dan semakin dipatuhinya pengendalian intern tersebut, maka semakin efektif pengelolaan piutang yang dilakukan 
oleh pihak manajemen perusahaan dalam menunjang efektivitas perusahaan.

Adapun yang termasuk dalam unsurunsur pengelolaan piutang yang menjadi dasar terhadap pembahasan dan penilaian pengendalian intern yaitu:

\section{1) Struktur Organisasi yang Memisahkan Tanggung Jawab Fungsional Secara Tegas.}

Fungsi penagihan yang dilakukan oleh penagih perusahaan bertanggungjawab untuk melakukan penagihan piutang kepada para debitur perusahaan berdasarkan daftar piutang yang ditagih yang telah dibuat oleh bagian akuntansi.Sedangkan fungsi kas yang dilakukan oleh bagian kasir bertanggungjawab atas penerimaan kas tunai dari fungsi penagihan. Bagian Administrasi bertanggungjawab untuk menyetorkan kas yang diterima dengan segera ke bank dalam jumlah penuh.

Fungsi

akuntansi

bertanggungjawab dalam

melakukan pencatatan penerimaan kas dari piutang ke dalam jurnal yang diperlukan sebagai input data komputer untuk mencatat ke dalam buku besar dan buku besar pembantu untuk pelaporan dan mencatat penerimaan pembayaran piutang ke dalam kartu piutang.

Adanya pemisahan organisasi fungsi akuntansi secara struktural maupun organisasional dengan fungsi kas dan fungsi penagihan perusahaan akan mempersulit ruang gerak karyawan untuk melakukan kecurangan. pengendalian intern secara organisasional dapat dikatakan efektif untuk mencegah penyimpangan dan kecurangan.
2) Sistem Otorisasi dan Prosedur Pencatatan.

Dalam organisasi, setiap transaksi hanya terjadi atas dasar otorisasi dari pejabat yang memiliki wewenang untuk menyetujui terjadinya transaksi tersebut. Pada Lembaga bimbingan belajar $\mathrm{X}$ di Madiun setiap dokumen yang digunakan dalam prosedur penerimaan kas harus diotorisasi oleh pejabat yang berwewenang. Nota kredit yang diterima bendahara dari bank akan dicocokkan dengan penerimaan harian, apabila cocok bendahara akan mencatat penerimaan harian dan nota kredit ke dalam buku kas. Setelah itu bagian akuntansi menerima nota kredit dan melakukan verifikasi, Bagian akuntansi mencatat pembayaran piutang berdasarkan atas pemberitahuan dari debitur.

3) Praktik yang Sehat dalam Melaksanakan Tugas dan Fungsi Setiap Unit Organisasi.

Dari hasil penelitian mengenai analisis pengelolaan piutang, pembayaran piutang dicatat dalam kartu piutang dan bagian akuntansi menginput jurnal yang diperlukan sebagai input data komputer, untuk penerimaan tunai disetor penuh ke bank dengan segera.

Para penagih dan bendahara perusahaan tidak ada jaminan oleh perusahaan. Hal ini memungkinkan terjadinya kecurangan yang dilakukan oleh karyawan bagian bendahara dan penagih, karyawan yang langsung berhubungan dengan uang perusahaan ini perlu ada jaminan, sehingga jika ada kerugian 
jaminan itu yang menanggung risiko kerugian yang timbul.

Kas dalam perjalanan juga tidak ada jaminan keberadaannya. Seharusnya jaminan diperlukan untuk melindungi kekayaan perusahaan berupa uang yang dibawa oleh penagih, Dengan dilaksanakannya praktik akuntansi yang sehat tersebut, maka akan mendukung efektivitas dan efisiensi perusahaan, di mana pada intinya perusahaan tidak akan dirugikan karena adanya penyelewengan yang dilakukan karyawan.

4) Karyawan yang Mutunya Sesuai dengan Tanggung Jawabnya.

Setiap penerimaan karyawan pada Lembaga bimbingan belajar $\mathrm{X}$ di Madiun diadakan seleksi secara objektif untuk mendapatkan karyawan yang bermutu, yang memiliki pengetahuan dan kecakapan yang sesuai dengan bidang masing-masing, kemudian dilatih dan dikembangkan agar menjadi pegawai yang cakap melaksanakan tugas yang dipercayakan kepadanya. Pengadaan traning, pelatihan danseminar-seminar diharapkan dapat meningkatkan mutu karyawan.

\section{Pengelompokan Piutang (Sekedul Piutang)}

Pengelolaan piutang juga sangat penting dilakukan oleh Lembaga bimbingan belajar $\mathrm{X}$ di Madiun karena untuk mengurangi kerugian ekonomis akibat hilangnya kesempatan untuk memeproleh pendapatan dan meminimalisir piutang. Dilihat dari pengamatan yang telah dilakukan peneliti setiap tahun piutang usaha mengalami kenaikan yang signifikan dan perusahaan terus mengalami kenaikan potensi piutang tidak dapat tertagih maka dari itu perusahaan perlu melukan tindakan penagihan yang agresif dalam artian dilakukan terus menerus dan menerapkan kebijakan piutang yang lebih ketat serta memiliki cadangan penghapusan piutang tidak dapat ditagih, dari resiko tersebut perusahaan perlu andanya cadangan penghapusan piutang tidak tertagih untuk perkiraan penilaina piutang usaha. Cadangan penghapusan piutang yang diperkirakan tidak dapat ditagih dalam tingkat penghapusanya disesuaikan dengan tingkat umur kedaluarsa piutang yang bersangkutan dengan jatuh tempo waktu \pm 60 hari.

\section{KESIMPULAN DAN SARAN \\ Kesimpulan}

Dari hasil penelitian yang dilakukan pada Lembaga bimbingan belajar X di Madiun, maka peneliti mengambil kesimpulan bahwa pengelolaan piutang dan potensi piutang yang tidak tertagih di lembaga bimbingan belajar X di Madiun sudah ada perbaikan di tahun ajaran baru 2016-2017

Perusahaan perlu melakukan tindakan penagihan yang agresif dalam artian dilakukan terus menerus dan menerapkan kebijakan piutang yang lebih ketat serta melibatkan bagian kesiswaan untuk membantu kelancaran penagihan yaitu dengan melakukan pendekatan ke siswa yang belum melakukan pelunasan.

\section{Saran}

1. Bagi Perusahaan

a. Para penagih dan kasir hendaknya ada jaminan (fidelity bond insurance) untuk menghindariterjadi kerugian yang besar.

b. Kas yang ada di tangan dan bagian kasir seharusnya ada jaminan mengingat jumlahnya cukup besar.

c. Pengawasan sudah baik namun lebih efektifnya hendaknya pengawas lebih sering dalam melakukan pengawasan untuk pengecekan dan 
pemantauan untuk menghindari kesalahan yang dapat ditimbulkan dalam kerugian operasional.

d. Perusahaan mengelompokan piutang untuk meminimalkan piutang tidak tertagih dan memudahkan manajemen dalam mengevaluasi.

2. Peneliti selanjutnya sebagai berikut :

a. Hendaknya peneliti mengambil objek lebih dari satu perusahaan sehingga dapat membandingkan dengan perusahaan lain.

b. Diharapkan dimasa yang akan datang dapat digunakan sebagai salah satu sumber data untuk penelitian lebih lanjut berdasarkan factor lainya dan tetap berhubungan dengan pengelolaan piutang dan potensi piutang yang tidak tertagih .

\section{DAFTAR PUSTAKA}

Atmaja, Lukas Setia, 2008, Teori dan praktek Manajemen Keuangan, Yogyakarta, penerbit ANDI.

Ahmad Syafi'I Syakur, Intermediate Accounting, AV Publisher, Jakarta, 2009.

Arnas, Aulia, Analisis Penerapan Pengendalian Intern Kas Pada PT Kaltim Nusa Etika (KNE) di Bontang, Fakultas Ekonomi Universitas Mulawarman.

Bambang, Dasar-dasar Pembelanjaan Perusahaan, Edisi Keempat. Dosen Fakultas Ekonomi Fakultas Gadjah Mada.

Brigham, Eugone F and Joel F.Houston, 2006. Dasar-dasar manajemen keuangan, alih bahasa Ali akbar Yulianto, buku satu,edisi 10, PT. Salemba Empat, Jakarta.

Baridwan, Zaki, 2004, Intermediate Accounting, Edisi Kedelapan, Yogyakarta;BPFE.

Donald E Kieso, Jerry J, Weygandt, Terry D. Warfield. 2008.Akuntansi
Intermediate, $\quad$ Edisi 12. Jakarta.Erlangga.

Erdi Kurniawan Syahputra, Siti Khairani. Skripsi, Analisis Piutang Tak Tertagih Pada PT. Bima Finance Palembang, STIE MDP.

Faradhillah, Ami. 2007. Analisa Prosedur Persetujuan Kredit Dalam Memperkecil Resiko Kerugian Piutang Tak Tertagih Pada Pt.Federal International Finance (Fif) Cabang Kisaran. Universitas Sumatera Utara. Fakultas Ekonomi Program S-1 Ekstensi Medan.

Gay, L.R. (1981). Educational Research. Ohio: A Beel \& Howell Company.

Hartati, Dian. 2010. Analisis Pengendalian Intern Piutang Usaha Pada PT. SFI Medan. Fakultas Ekonomi Medan. Universitas Sumatera Utara.

Kasmir. 2008. Bank dan lembaga keuangan lainya. Edisi Revisi 2008.Jakarta: PT. RAJAGRAFINDO PERSADA.

Mulyadi. 2001. Sistem Akuntansi, Edisi Ketiga. Jakarta: Salemba Empat.

Nur Farhanah. 2009. Analisis penerapan kebijakan manajemen piutang $P T$. Wijaya Indonesia Makmur cabang setia budi. Medan

Puspitasari, Setyo Maruli. 2004. Analisis sistem pengendalian intern atas pengelolaan piutang usaha pada $P T$. PLN (Persero) unit pelayanan dan jaringan Blitar. Universitas Negeri Malang. Malang

Suprihatmi Sri Wardiningsih, Jurnal, Analisis pengelolaan Piutang Sebagai Tindak Lanjut Kebijakan Penjualan Kredit, Fakultas Ekonomi Universitas Slamet Riyadi Surakarta.

Siahaan, Debora. 2010. Analisis penerapan kebijakan piutang serta pengaruhnya terhadap cash ratio, net profit margin, dan earning power pada perusahaan PT. Wijaya Indonesia 
Makmur Bicycle Indrustriy cabang Setia Budi Medan. Fakultas Ekonomi Medan. Universitas Sumatera Utara. Skousen, Stice, 2001. Akuntansi Keuangan Menengah. Edisi kesembilan, JilidSatu, Terjemahan. Salemba Empat, Jakarta.

Utami, saputri. 2011. Pengaruh sistem pengendalian intern piutang terhadap kelancaran penerimaan piutang pada koperasi karyawan omedata (KKO). Universitas Pendidikan Indonesia. Bandung

Wicaksana, Indrajid. 2011. Analisis Pengaruh Pengendalian Piutang terhadap Efektivitas Arus Kas (Studi Kasus pada PT. Z). Fakultas Ekonomi dan Manajemen Institut Pertanian Bogor. Bogor

Venny, Grace. Jurnal. Analisis Piutang Pada PT. SUCOFINDO (Persero) cabang Manado, Fakultas Ekonomi dan Bisnis, Fakultas Ekonomi dan Bisnis Universitas Sam Ratulangi Manado.

Van Horne, James C. and John M. Wachowicz. 2005. Fundamentals of Financial: Management PrinsipPrinsip Manajemen Keuangan. Penerjemah: DewiFitriasari dan Deny Arnos Kwary. Penerbit Salemba Empat: Jakarta. 